RESEARCH ARTICLE

\title{
MENS REA AND STATE LOSES ON CORRUPTION CASES: AN ANALYSIS OF CORRUPTION COURT JUDGMENT OF SEMARANG
}

\author{
Alif Kharismadohan ${ }^{{ }_{凶}}$ \\ ${ }^{1}$ Postgraduate Program, Master of Laws, Universitas Negeri Semarang \\ $\triangle$ alifkharismadohan@gmail.com
}

HOW TO CITE:

Kharismadohan, A. (2020). Mens Rea and State Loses on Corruption Cases: An Analysis of Corruption Court Judgment of Semarang. Journal of Law and Legal Reform, 1(1), 61-76. DOI: https://doi.org/10.15294/jllr.vlil.35407

\begin{abstract}
Quality Judges' decisions are decisions that are based on legal considerations according to the facts revealed at the trial, according to the laws and beliefs of the judge without being influenced by various external and internal interventions. The results of this study indicate that the judge in giving the decision still considers the overall elements included in Law No. 31 of 1999 jo. Law No. 20 of 2001 concerning Eradication of Corruption and Amendments to Law Number 31 of 1999 concerning Eradication of Corruption Crime, including elements of the evil spiritual attitude (mens rea). In the case of even being caught, mens rea is still important to prove at the trial stage. Basically, this mens rea becomes an important element to determine the accountability of the perpetrator. However, in cases of corruption, it is often difficult to find mens rea, even though in the examination it indicates that there is a State loss that arises in an event of corruption. The conclusions of this study are the consideration of the judge in giving a decision, always considering the elements of the crime, then things that alleviate, things that are burdensome than the attitude of the defendant including mens rea or malicious intent.
\end{abstract}

Keywords: Mens Rea; Corruption; Judgment; Judge Decision; Intention 


\section{TABLE OF CONTENTS}

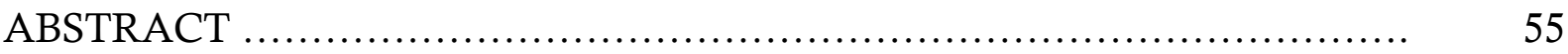

TABLE OF CONTENTS ....................................................... 56

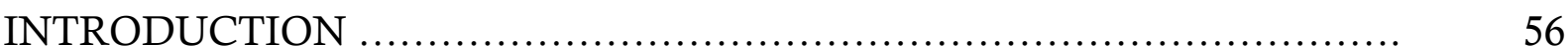

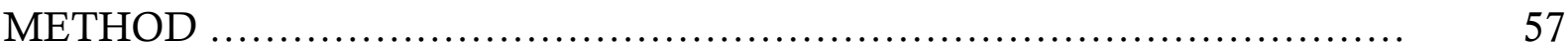

JUDGE'S CONSIDERATIONS IN GIVING DECISIONS ON

CORRUPTION CASES ..................................................... 57

I. JURIDICAL CONSIDERATIONS ........................................ 58

A. Judge's Rationale for Decision Making .................................. 58

B. Cases of Corruption Crime …........................................ 58

II. JUDGE'S CONSIDERATIONS IN THE CONTEXT OF MENS REA ...... 60

A. Non-Juridical Considerations .............................................. 62

B. Limitation on Value of State Losses which are Included in the category of Enriching and/or Profitable in Corruption ........................... 62

C. Application of Enriching and/or Self-Benefiting Elements by Judges in Criminal Acts of Corruption .............................................. 63

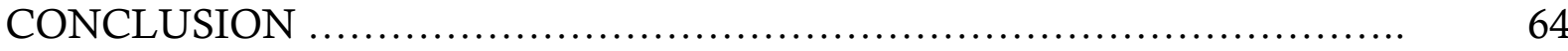

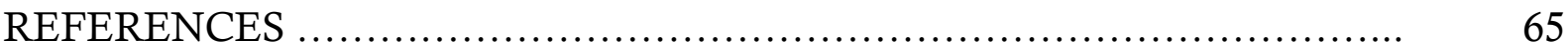

\section{INTRODUCTION}

The Indonesian Transparency Society notes that Indonesia is the third most corrupt country in the world after Kamboja. Corruption in Indonesia is in danger position. Corruption practices in Indonesia are increasing from year to year, both of the state's financial losses and increasingly systematic quality, more sophisticated and relevant in all aspects of society (Mazzi et al., 2019). The increase in corruption is uncontrolled. It brings many problems, not only national economic life but also the nation and state life in general. The rise of corruption cases in Indonesia, no longer knows the limits of who, why and how. It is not only the functionary and the stakeholders that committing crimes of corruption but also in the public and private sectors, corruption has become a phenomenon (Reichborn-Kjennerud et al., 2019).

Corruption is an extraordinary crime, because it can damage the joints of state life (Mocetti and Orlando 2019). This is the same as the opinion of Mahfudz Ali in the journal International Journal of Business, Economics, and Law, Vol.14, Issue4 (December) ISSN 2289-1552, "Corruption eradication is used in ways that are out of the ordinary by freeing themselves from legal efforts towards textual to contextual". However, in the reality, the sentencing of the perpetrators is very minor compared to the threat of criminals, which raises the assumption that the increase in crime is because the Judges give light sentences for corruptors. Therefore, the actions taken by the court 
are "ultimum remedium" against violators/perpetrators of crime, especially corruption (Policardo, Sanchez Carrera, and Risso 2019).

Quoted from South East Asia Journal of Contemporary Business, Economics, and law, Vol.13, Issue4 (August) 2017, "The head of the Corruption Court has the authority to determine the composition according to the requirements case. Obviously in Article 26 (3): "The act of determining the number and composition of the panel of judges as described in (1) and (2) are carried out by each Chairperson of the Corruption Court or Chair of the Supreme Court according to level and means of investigation of each case" (Tran, 2019).

Furthermore, even in criminal sentences, there are striking differences in the length of time an accused is sentenced to prison with the same article, namely Article 3 of the Republic of Indonesia Law Number 31 of 1999 jo. Republic of Indonesia Law Number 20 of 2001 Concerning Amendments to Republic of Indonesia Law Number 31 of 1999 Concerning Eradication of Corruption. In addition, in practice, there are also things that are overlooked, because in consideration of the Judge's decision that does not clearly and expressly distinguish the nominal value of the loss of the state lost due to the act of the convicted (Junxia, 2019; Arifin, 2016; Arifin, Utari, \& Subondo, 2016; Fitriyaningrum, \& Arifin, 2019). The point is that the Judge has not made a distinction on the definition of the element of enriching and/or benefiting oneself or another person or a corporation for any corruption case that has been decided, resulting in the imposing of punishment being disproportionate (Qu et al., 2019).

On the basis of the description above, the author wants to explore the judges' consideration study in the form of a thesis with the theme: Decision of Corruption Criminal Act: Study of the Consideration of Mens Rea Elements and State Losses Elements Included in the category of Enriching and/or Beneficial in Corruption Crimes in the Semarang Corruption Court. The formulation of the problems that arise in this study are as follows:

1. How is the judge's consideration in giving a decision on a corruption case and is the inner attitude (mens rea) a dominant element in the consideration?

2. How are the limits of the value of state losses that fall into the category of enriching and/or beneficial in corruption?

3. How is the application of the element of enriching and/or benefiting oneself by the judge in the criminal act of corruption?

\section{METHOD}

This study uses qualitative research methods with the type of sociological juridical approach. Primary data: Judge who has decided on corruption in the Semarang City Corruption Court. Secondary: Books on law, related to Criminal Law Enforcement, and Law No. 31 of 1999 concerning Eradication of Corruption Crimes jo. Law No. 20 of 2001 concerning Amendments to Law Number 31 of 1999 concerning Eradication of Corruption (Jha, 2019). 


\section{JUDGE'S CONSIDERATIONS IN GIVING DECISIONS ON CORRUPTION CASES}

The judge in giving decisions considers juridical factors and non-juridical factors. For this reason (Kalyuzhnova and Belitski 2019). The description in this sub-chapter is for the juridical consideration and non-juridical consideration.

\section{JURIDICAL CONSIDERATIONS}

A. Judge's Rationale for Decision Making

Law No. 31 of 1999 jo.UU No.20 of 2001 concerning Eradication of Corruption highlighted 30 forms or types of corruption have been formulated in which cases that often occur are violations of Article 2 and Article 3 of the subjective elements contained in both the article, can be seen how the concept of criminal responsibility is actually in the criminal act of corruption (Jin, Chen, and Luo, 2019).

As Rusli Muhammad's opinion (Rusli, 2007) that judges considerations in issuing decisions can be divided into two categories, namely:(1). Judicial judgments, and (2). Nonjudicial judgments. In judicial considerations are judges' considerations that are based on juridical facts revealed in court proceedings and are determined by law to be contained in a decision (H. Zhang et al., 2019). These matters include:

a. Public prosecutor's indictment

b. Defendant's statement

c. Witness statement

d. Evidence

e. Articles in the Criminal Law regulations

The description below contains the position of the case, the indictment of the Public Prosecutor, the defendant's statement, witness testimony, evidence and articles contained in the legislation.

\section{B. Cases of Corruption Crimes}

The defendant Akhmad Said bin Muhaemin stated that the defendant as the village secretary in Wanatawang Village when receiving, controlling and using the village cash rent or the crooked land of the village had signed material evidence in the form of the crooked land rent receipt for the Karangbinangun Hamlet for 2 (two) shoulder and Bajangan block area of 2 (two) shoulders from SUBUR witnesses and KASIRIN witnesses, which in turn will rent Village/Tanah Bengkok Village cash for the Karangbinangun Hamlet block of 2 (two) shoulders and Bajangan block area of 2 (two) shoulders This will be used in the interests of the administration of the village administration, which in fact the defendant has no right to do so, but the defendant continues to do so. 


\section{1) Indictment of Public Prosecutors}

The public prosecution's claim states as follows:

a. State the defendant Akhmad Said Bin Muhaemin has been proven legally and convincingly guilty of committing a criminal act of Corruption, as regulated and threatened with crime in Article 3 Jo Article 18 of Law No. 31 of 1999 concerning Eradication of Corruption Crimes Jo Law No. 20 of 2001 concerning Amendments to Law No. 31 of 1999 concerning Eradication of Corruption Crimes Jo. Article 64 paragraph (1) of the Criminal Code as charged in the Subsidiary indictment.

b. Dropping the criminal offense against the defendant Akhmad Said Bin Muhaemin with imprisonment for 2 (two) years and 6 (six) months reduced while the defendant is in temporary custody, with the order that the defendant remains detained.

c. Drop the criminal charge for the defendant to pay a fine of Rp. 50,000,000 (fifty million rupiahs) Subsidiary 3 (three) months in captivity.

d. Ordered the defendant to pay a replacement fee of Rp.160,000,000 (one hundred sixty million rupiahs), taking into account the amount of money returned by the defendant in the amount of Rp. 45,000,000.00 (forty-five million rupiahs) subsequently counted as a replacement payment with the provision that no later than 1 (one) month after the court's decision has legal force, the convict does not have sufficient assets to pay the remaining balance then replaced with imprisonment for 1 (one) year and 3 (three) months.

\section{2) Defendant's Statement}

a. The defendant frankly admitted his actions;

b. The defendant behaves politely in court;

c. The defendant had a good intention to leave a personal fund of Rp. 45,000,000.00 (forty-five million rupiahs) to the state even though the defendant felt that he did not commit acts that could harm the country;

d. The defendant is the head of the household who has a family dependent;

e. The accused was ostracized by his extended family because of an alleged act that he did not actually commit;

f. Defendants included low human resources so they could not do the administration properly;

g. The defendant is truly very sorry and will be more careful in carrying out the people's mandate.

\section{3) Evidence}

Determine that the Evidence is in the form of:

a. 1 (one) photocopy of excerpt from the Brebes Regent Number 821.1/052.B of 2010 dated January 29, 2010, concerning the appointment of civil servants on behalf of Akhmad Said following l (one) attachment sheet;

b. 2 (two) sheets of receipt of rent for crooked land of the former village secretary on behalf of Br Kasirin, respectively dated October 5, 2011, and July 27, 2012; 
c. 6 (six) receipts of bent land leases of former Sekdes on behalf of brothers Subur Bin Kasmadi, each dated March 1, 2008, dated July 14, 2009, dated April 10, 2010, dated May 23, 2010, dated August 10, 2010, and dated 28 August 2010, and dated 28 August 2010. February 2011;

d. 2014 General Cash Book Ds. Wanatawang, Songgom District, Brebes Regency. All of them were returned to Wanatawang Village.

\section{4) Articles in Criminal Law Regulations}

The defendant's actions were submitted to the court by the Public Prosecutor with the following indictments: It has been proven legally and convincingly guilty of committing a Corruption, as regulated and threatened with criminal offenses in Article 3 Jo Article 18 of Law No.31 of 1999 concerning Eradication of Corruption Crimes Jo Law No. 20 of 2001 concerning Amendments to Law No. 31 of 1999 concerning Eradication of Corruption Crimes Jo. Article 64 paragraph (1) of the Criminal Code as charged in the subsidiary indictment.

\section{5) Judge's Decision}

Case Study Results of the Corruption TP Case that was decided by Judge Edy Sepjengkaria, SH., CN., MH, in Semarang District Court against Corruption Crimes, among others: The decision of the Corruption Court at the Semarang District Court Number 121/Pid.Sus-TPK/2016/PN.Smg.an. The Defendant Akhmad Said, That the defendant as the Village Secretary in the Village of Wanatawang when receiving, controlling and using the rent of the village treasury or the crooked land of the village had signed the material evidence in the form of the receipt of the crooked land lease for the Karangbinangun Hamlet block of 2 (two) shoulder and Bajangan block area of 2 (two) shoulders from witness SUBUR and KASIRIN witnesses, which will later rent Village/Land Crooked Village cash for the Karangbinangun Hamlet area of 2 (two) shoulders and Bajangan block area of 2 (two) shoulders will be used in the interests of the administration of the village government, which in fact the defendant has no right to, but the defendant still does.

Judge's considerations in giving decisions, always consider the elements of the crime, then mitigating matters, incriminating matters and then the attitude of the accused including mens rea or malicious intent (Gründler and Potrafke, 2019). Then the victims incurred for their actions whether it concerns the community or individual influence on consideration. Besides considering the above matters, the judge's judgment is also based on the value of the losses incurred. Related to the elements in corruption from a legal point of view, in general, meet the following elements (J. Zhang, Quan, and Jiang, 2019):
a. acts against the law
b. abuse of authority, opportunity or means,
c. enrich yourself, others, or corporations, and
d. harms the country's finances or the country's economy 
Where the explanation regarding the elements of criminal acts of corruption is listed in Article 2 and Article 3 of Law Number 31 of 1999 concerning Eradication of Corruption.

\section{JUDGE'S CONSIDERATIONS IN THE CONTEXT OF MENS REA}

In the case of Corruption, consideration of malicious attitudes and intentions, whether intending to enrich oneself, or others, or in carrying out administrative errors, is a case with different considerations. In extracting data through interviews with the Semarang District Court Corruption Judge, the court stated that:

In the phenomenon of various types of Corruption, some have been regulated from the beginning, from an auction that has been won by their colleagues or colleagues. There is also a smooth start, in the middle of the trip replace cheaper wood, from the beginning there was no intention but maybe in the middle of the road there is an offer of cheaper goods, then the evil intent is not from the beginning. Compared to murder, it is planned murder by meeting people and then killed for fighting, then the punishment will be different. Then bad intentions will affect decision making. The inner element when it is said to be dominant or not dominant is unity so all is dominant between the behavior of the act together (Interview with Corruption Judge Mr. Edy Sepjengkaria, SH CN MH On 7 February 2019).

On the other hand in criminal theory, a crime is built on two important elements, namely the objective/physical element, namely actus reus (acts that violate criminal law) and subjective/mental elements, namely mens rea (the inner attitude of the perpetrator when committing a crime) (Trifonova Price, 2019). In criminal law enforcement procedures (criminal procedure), there are two opinions about which one should be seen first, actus reus or mens rea?

However, the judge in his decision when giving consideration for corruption cases, actus reus and mens rea became the main and very important basis(Akbari, Bahrami-Rad, and Kimbrough 2019). For this reason, the absence of mens rea in a corruption case is often a consideration for determining whether or not corruption suspects are detained (Ullah, 2019).

Does the mens rea then have to be seen from the beginning of the investigation process to determine whether the suspect can be detained or not? Returning to the initial concept of the element of the crime, actus reus, and mens rea must exist in a criminal act, but no provisions on mens rea must be seen at an early stage, moreover making it the main basis for detention (Dong, Zhang, and Song, 2019).

The basis for detention according to the Criminal Procedure Code (KUHAP) is the authority of the investigator to detain a suspect if there is a concern that the 
suspect will Hiding evidence, Escape, and Repeat the crime (Dincer and Teoman, 2019).

The conclusion of the author in this case, in exploring the placement of mens rea to be made by judges for consideration is flexible and casuistic where mens rea will meet its final place, namely in the courtroom where it (mens rea) will be proven (Batzilis, 2019). As actus, reus will also be examined whether it is true against criminal law or not, in court (Wang and Zheng, 2019).

For corruption cases, the author believes strict liability is appropriate as a form of accountability, so that the element of mens rea becomes irrelevant in the examination procedure, especially if it is then used as a basis for not continuing the examination of corruption (Erum and Hussain, 2019). For detention, the basis for detention is to detain the suspect if there is a concern that the suspect will hide evidence, escape, repeat the crime as determined by the Criminal Procedure Code (Imam, Jamasb, and Llorca, 2019).

All are entirely dependent on the case investigator in question. So that it will withhold or not withhold, the reason can be found in the investigator's consideration. In essence, when the perpetrators' actions are said to have complied with the offense, the investigator only needs to see whether the perpetrators have mens rea for the actions so that criminal liability can be held (Akhbari and Nejati, 2019). The criminal law doctrine says that criminal liability is determined by mistakes made by the offender. There are two errors, namely intentional (dolus) and negligence (culpa) (Brada et al., 2019).

Therefore, the public prosecutor understands the meaning of the actus and mens rea in eradicating corruption, so it is almost certain that no suspect will win in the pre-trial forum or the defendant is convicted by the court (Borsky and Kalkschmied, 2019). Because investigators have ensured that the perpetrators' actions are possessed of dolus malus, the perpetrators are to blame and cause consequences in the form of state financial losses. Although the offense of corruption is not merely a loss of state finances (Changwony and Paterson, 2019).

\section{A. Non-Juridical Considerations}

1) The defendant's background

The background of the defendant's actions is any circumstance that causes the desire and hard drive of the defendant to give birth to a criminal offense.

2) As a result of the defendant's actions

The criminal act committed by the defendant is sure to bring the victim or loss to another party. Even as a result of the defendant's actions from the crime committed can also adversely affect the wider community, at least their security and peace are always threatened.

3) The defendant's condition

The definition of the defendant's self condition is the physical or psychological state of the defendant before committing the crime, including the social status attached to the defendant. Physical intended is the age and level of maturity, while 
the intended psychological state is related to feelings that can be: get pressure from others, chaotic thoughts, angry states, and others.

4) Defendant's religion

The attachment of judges to religious teachings is not enough to simply put the word "Godhead" on the head of the verdict, but must be a measure of evaluation of every action both the actions of the judges themselves and especially the actions of the criminals.

\section{B. Limitation on Value of State Losses which are Included in the category of Enriching and/or Profitable in Corruption}

Corruption has resulted in a fairly high level of loss to the economy and state finances (Rimšaitè, 2019). Therefore, it can be said that corruption is a violation of human rights, namely the collective rights of the people, which due to the leakage of the people become poor and hampered their rights to achieve economic progress due to the powerlessness of the government in carrying out development (Branco, Delgado, and Turker, 2019).

Regarding the element of "adverse state finance" law enforcement agencies work together with related agencies namely BPK or BPKP which helps investigators calculate state losses (Sheng, Zhou, and Zhang, 2019). In general, criminal acts of corruption are the abuse of authority and power for the benefit of themselves or certain groups, so the main variable in corruption is power (Lima and Delen, 2019). In other words, those who have power, especially over public resources, will have a great opportunity to commit acts of corruption, whereas, in the context of regional autonomy, criminal acts of corruption occur following decentralized power to the local level (Choudhury, 2019).

However, losses to the state's finances or the country's economy (state losses) are not a condition for the occurrence of non-criminal corruption Article 2 perfectly, but due to state losses can arise from acts of enriching themselves against the law. Its size can cause harm which is based on experience and logic/common sense of people by paying attention to various aspects around actions that are categorized as enriching themselves (Le Moglie and Turati, 2019).

\section{Application of Enriching and/or Self-Benefiting Elements by Judges in Criminal Acts of Corruption}

This corruption offense related to acts of enriching oneself and/or other people or an entity (corporation) that can harm the state finances by means of violating the law are listed in Article 2 of Law Number 31 of 1999 jo. Law Number 20 of 2001. The law is often implemented in most Corruption Courts, including in the Semarang Corruption Court, this article is the most frequently used in trials to ensnare perpetrators of corruption (Lombardi et al., 2019).

Specifically, in Article 2 paragraph (1), it is regulated on the element of "enriching" and on Article 3 on the element of "favorable", if you see the provisions of Law Number 31 of 1999 concerning Eradication of Corruption Crimes jo. Law Number 
20 of 2001 concerning the amendment of Law Number 31 of 1999 concerning Eradication of the Corruption Act. However, the explanation section of the corruption law does not explain the criteria at all rather than the element of "enriching" and/or "beneficial" elements so that it can have multiple interpretations when interpreting them (Bašná, 2019). In the explanation part it only states that in order to achieve more effective goals to prevent and eradicate criminal acts of corruption, this corruption law contains criminal provisions that specify specific minimum criminal threats, higher criminal penalties, and the death penalty. Thus, none of the similarities found in the formulation of the notion of "enriching" or "beneficial" both in the regulation of the law and in the opinion of experts in determining a certain amount of value, or the criteria of a person or corporation can be said as a matter of enriching or beneficial, except only stating an increase in assets for other actors/persons (Arifin, 2016; Arifin, Utari, \& Subondo, 2016; Fitriyaningrum, \& Arifin, 2019).

Therefore, this shows that the Judge has the authority to exercise discretion in determining the penalty for corruptors for the element of "enriching" between a minimum sentence of 4 (four) years and a maximum life sentence or death sentence. Likewise, the fine follows the maximum fine in accordance with the provisions above. Thus, the application of criminal sentences with minimal and maximum threats, which should have an imperative nature when viewed from Law No. 31 of 1999 concerning the Eradication of Corruption. However, in practice, it has a limitation of nature, which results in achieving more effective goals to prevent and eradicate corruption from experiencing difficulties. Especially when looking at the editorial of articles such as the element of "enriching" and/or "beneficial" elements in the law in question, which have not been clearly stipulated on the criteria/understanding, so that it can have an impact on multiple interpretations (Sinha et al,. 2019). So far, there have been many decisions made by judges on criminal acts of corruption that do not contain clear legal considerations, especially regarding the differentiation of the criteria of the element of "enriching" and/or "beneficial" elements (Thakur and Kannadhasan, 2019).

The final verdict on a criminal case in the Criminal Procedure Code is handed over to the Judge and the Judge will render the decision based on legal evidence plus his conviction (Titeca and Edmond, 2019). A Judge's ruling would ideally provide justice for all parties, while at the same time providing legal benefits and certainty, despite the fact that accommodating justice between the accused and the injured community as well as in the ruling is not easy, because justice is related to a subjective sense whose benchmarks are very relative (Nur-tegin and Jakee, 2019). Despite the difficulty of finding the right parameters to determine justice in exercising his authority to judge, Judges have the freedom guaranteed by the constitution and the law. 


\section{CONCLUSION}

Judges in ruling decisions always consider two things, namely (1) Juridical considerations, and (2) Non-juridical considerations. In terms of judicial considerations the judge bases on: Public prosecutor's indictment, Defendant's statement, Witness statement, Evidence, and Articles in the Criminal Law regulations. Associated with non-juridical considerations, are matters that relieve, things that are burdensome than the attitude of the defendant including mens rea or evil intentions. The following are judges' considerations in a non-juridical manner: The defendant's background, As a result of the defendant's actions, and The defendant's condition.

In the case of mens rea, the judge's consideration in giving a ruling looks at: Judge's considerations in giving decisions, always consider the elements of the crime, then mitigating matters, incriminating matters and then the attitude of the accused including mens rea or malicious intent. Then the victims incurred for their actions whether it concerns the community or individual influence on consideration. Besides considering the above matters, the judge's judgment is also based on the value of the losses incurred. Related to the elements in corruption from a legal point of view, in general, meet the following elements: acts against the law, abuse of authority, opportunity or means, enrich yourself, others, or corporations, and harms the country's finances or the country's economy.

These four elements are included in Law No. 31 of 1999 jo. Law No. 20 of 2001 concerning Eradication of Corruption and Amendments to Law Number 31 of 1999 concerning Eradication of Corruption. In the corruption offense, the emphasis is different, if compared with the illustration of the offense above or other ordinary crimes. The responsibility is strict liability. Whatever the mens rea, if it is proven that the actus reus has the consequences referred to in the Anti-Corruption Law, then the perpetrators can be convicted. Here, the element of actus reus: the element of mens rea is 100: 0 . The case of corruption is not determined by mens rea, but actus reus which fulfills the Corruption Act formally, and sufficient evidence to prove the consequences prohibited by the law (material offense) did happen. The paper highlighted that in exploring the placement of mens rea to be made by judges for consideration is flexible and casuistic where mens rea will meet its final place, namely in the courtroom where mens rea will be proven. As actus reus will also be examined whether it is true against criminal law or not in court.

Furthermore, in order to be able to eradicate corruption in an effective manner it is necessary to have statutory provisions that at least meet the following requirements: (1) has a clear editorial and is easily understood by anyone and measured the nominal value of the loss of the country; and (2) criminal threats must be rational and proportional, meaning that criminal threats must be adjusted to the consequences caused by the criminal act itself.

In the application of the element of enrichment and self-benefit, the judge has the authority to exercise discretion in determining the penalty for corruptors over the "enrichment" element between a minimum sentence of 4 (four) years and a maximum 
life sentence or death sentence. Likewise, the fine follows the maximum fine in accordance with the provisions above. Thus, the application of criminal sentences with minimal and maximum threats, which should have an imperative nature when viewed from Law Number 31 of 1999 concerning the Eradication of Corruption. However, in practice, it has a limitation of nature, which results in achieving more effective goals to prevent and eradicate corruption from experiencing difficulties. Especially when looking at the editorial of articles such as the element of "enriching" and/or "beneficial" elements in the law in question, which have not been clearly stipulated on the criteria/understanding, so that it can have an impact on multiple interpretations. So far, there have been many decisions made by judges on criminal acts of corruption that do not contain clear legal considerations, especially regarding the differentiation of the criteria of the element of "enriching" and/or "beneficial" elements.

\section{REFERENCES}

Akbari, M., Bahrami-Rad, D., \& Kimbrough, E.O. (2019). Kinship, Fractionalization and Corruption. Journal of Economic Behavior and Organization, 15(1), 164. https://ssrn.com/abstract=2847222 or http://dx.doi.org/10.2139/ssrn.2847222.

Akhbari, R., \& Nejati, M. (2019). The Effect of Corruption on Carbon Emissions in Developed and Developing Countries: Empirical Investigation of a Claim. Heliyon, 5(9), e02516. https://doi.org/10.1016/j.heliyon.2019.e02516.

Arifin, R. (2016). Analisis Hukum Internasional Dalam Perampasan Aset Di Negara Kawasan Asia Tenggara Berdasarkan United Nations Convention Against Corruption (UNACA) dan Asean Mutual Legal Assistance Treaty (AMLAT)" Jurnal Penelitian Hukum, 3(1), 37-55.

Arifin, R., Utari, I.S., \& Subondo, H. (2016). Upaya Pengembalian Aset Korupsi Yang Berada Di Luar Negeri (Asset Recovery) dalam Penegakan Hukum Pemberantasan Korupsi di Indonesia. Indonesian Journal of Criminal Law Studies, 1(1), $105-137$.

Bašná, K. (2019). Income Inequality and Level of Corruption in Post-Communist European Countries between 1995 and 2014. Communist and Post-Communist Studies, 52(2), 93-104.

Batzilis, D. (2019). Electoral Competition and Corruption: Evidence from Municipality Audits in Greece. International Review of Law and Economics, 59(1), 1320. https://doi.org/10.1016/j.irle.2019.04.003.

Borsky, S., \& Kalkschmied, K. (2019). Corruption in Space: A Closer Look at the World's Subnations. European Journal of Political Economy, 59(4), 400-422. https://doi.org/10.1016/j.ejpoleco.2019.05.004.

Brada, J. C., rabek, Z., Mendez, J.A., \& Perez, M.F. (2019). National Levels of Corruption and Foreign Direct Investment. Journal of Comparative Economics, 47(1), 31-49. https://doi.org/10.1016/j.jce.2018.10.005.

Branco, M.C., Delgado, C., \& Turker, D. (2019). Liability of Foreignness and AntiCorruption Reporting in an Emerging Market: The Case of Turkish Listed 
Companies. Journal of Cleaner Production, 232(1), 118-26. https://doi.org/10.1016/j.jclepro.2019.05.367.

Changwony, F.K, \& Paterson, A.S. (2019). Accounting Practice, Fiscal Decentralization and Corruption. British Accounting Review, 51(5), 100834. https://doi.org/10.1016/j.bar.2019.04.003.

Choudhury, S. (2019). WTO Membership and Corruption. European Journal of Political Economy, 60(December), 101806. https://doi.org/10.1016/j.ejpoleco.2019.07.004.

Dincer, O., \& Teoman, O. (2019). Does Corruption Kill? Evidence from Half a Century Infant Mortality Data. Social Science and Medicine, 232(May), 332-339. https://doi.org/10.1016/j.socscimed.2019.05.017.

Dong, B., Zhang, Y., \& Song, H. (2019). Corruption as a Natural Resource Curse: Evidence from the Chinese Coal Mining. China Economic Review, 57(1), 101314. https://doi.org/10.1016/j.chieco.2019.101314.

Erum, N., \& Hussain, S. (2019). Corruption, Natural Resources and Economic Growth: Evidence from OIC Countries. Resources Policy, 63(June), 101429. https://doi.org/10.1016/j.resourpol.2019.101429.

Fitriyaningrum, J., \& Arifin, R. (2019). The Regulatory Model for Eradication Corruption in Infrastructure Funding. Varia Justicia, 15(1), 36-42. https://doi.org/10.31603/variajusticia.vl5il.2421

Gründler, K., \& Potrafke, N. (2019). Corruption and Economic Growth: New Empirical Evidence. European Journal of Political Economy, 60 (December), 101810. https://doi.org/10.1016/j.ejpoleco.2019.08.001.

Imam, M. I., Jamasb, T., \& Llorca, M. (2019). Sector Reforms and Institutional Corruption: Evidence from Electricity Industry in Sub-Saharan Africa. Energy Policy, 129(February), 532-45. https://doi.org/10.1016/j.enpol.2019.02.043.

Jha, C.K. (2019). Financial Reforms and Corruption: Evidence Using GMM Estimation. International Review of Economics and Finance, 62(1), 66-78. https://doi.org/10.1016/j.iref.2019.03.003.

Jin, X., Chen, Z., Luo, D. (2019). Anti-Corruption, Political Connections and Corporate Responses: Evidence from Chinese Listed Companies. Pacific-Basin Finance Journal, 57(October), 101198. https://doi.org/10.1016/j.pacfin.2019.101198.

Junxia, L. (2019). Investments in the Energy Sector of Central Asia: Corruption Risk and Policy Implications. Energy Policy, 133 (June), 110912. https://doi.org/10.1016/j.enpol.2019.110912.

Kalyuzhnova, Y., \& Belitski, M. (2019). The Impact of Corruption and Local Content Policy in on Firm Performance: Evidence from Kazakhstan. Resources Policy 6l(January), 67-76. https://doi.org/10.1016/j.resourpol.2019.01.016.

Lima, M.S.M., \& Delen, D. (2019). Predicting and Explaining Corruption across Countries: A Machine Learning Approach. Government Information Quarterly, 25(1), 101407. https://doi.org/10.1016/j.giq.2019.101407.

Le Moglie, M., \& Turati, G. (2019). Electoral Cycle Bias in the Media Coverage of Corruption News. Journal of Economic Behavior and Organization, 163(1), 140-157. https://doi.org/10.1016/j.jebo.2019.05.005. 
Lombardi, R., Trequattrini, R., Cuozzo, B., \& Cano-Rubio, M. (2019). Corporate Corruption Prevention, Sustainable Governance and Legislation: First Exploratory Evidence from the Italian Scenario. Journal of Cleaner Production, 217(6) 666-675.

Mazzi, F., Slack, R., Tsalavoutas, I., \& Tsoligkas, F. (2019). Country-Level Corruption and Accounting Choice: Research \& Development Capitalization under IFRS. British Accounting Review, 51(5), 1-25. https://doi.org/10.1016/j.bar.2019.02.003.

Mocetti, S. \& Orlando, T. (2019). Corruption, Workforce Selection and Mismatch in the Public Sector. European Journal of Political Economy, 60(December), 101809. https://doi.org/10.1016/j.ejpoleco.2019.07.007.

Nur-tegin, K., \& Jakee, K. (2019). Does Corruption Grease or Sand the Wheels of Development? New Results Based on Disaggregated Data. Quarterly Review of Economics and Finance, 35(1), 1-20. https://doi.org/10.1016/j.qref.2019.02.001.

Policardo, L., Carrera, E.J.S., \& Risso, W.A. (2019). Causality between Income Inequality and Corruption in OECD Countries" World Development Perspectives 14(April), 1-3. https://doi.org/10.1016/j.wdp.2019.02.013.

Qu, G., Slagter, B., Sylwester, K., \& Doiron, K. (2019). Explaining the Standard Errors of Corruption Perception Indices. Journal of Comparative Economics, 47(4), 907-920. https://doi.org/10.1016/j.jce.2019.07.003.

Reichborn-Kjennerud, K., Gonzalez-Díaz, B., Bracci, E., Carrington, T., Hathaway, J., Jeppesen, K.K., \& Steccolini, I. (2019). Sais Work against Corruption in Scandinavian, South-European and African Countries: An Institutional Analysis. The British Accounting Review, 5l(5): 100842. https://doi.org/10.1016/j.bar.2019.100842

Rimšaitè, L. (2019). Corruption Risk Mitigation in Energy Sector: Issues and Challenges." Energy Policy 125(October), 260-266.

Sheng, J., Zhou, W., \& Zhang, S. (2019). The Role of the Intensity of Environmental Regulation and Corruption in the Employment of Manufacturing Enterprises: Evidence from China. Journal of Cleaner Production, 219(1), 244-257. https://doi.org/10.1016/j.jclepro.2019.02.113.

Sinha, A., Gupta, M., Shahbaz, M., \& Sengupta, T. (2019). Impact of Corruption in Public Sector on Environmental Quality: Implications for Sustainability in BRICS and next 11 Countries" Journal of Cleaner Production, 232(6), 1379-1393. https://doi.org/10.1016/j.jclepro.2019.06.066.

Thakur, B.P.S., \& $\mathbb{E}$ Kannadhasan, M. (2019). Corruption and Cash Holdings: Evidence from Emerging Market Economies" Emerging Markets Review, 38(1), 1-17. https://doi.org/10.1016/j.ememar.2018.11.008.

Titeca, K., \& Edmond, P. (2019). The Political Economy of Oil in the Democratic Republic of Congo (DRC): Corruption and Regime Control. Extractive Industries and Society, 6(2): 542-551. https://doi.org/10.1016/j.exis.2018.12.003.

Tran, Quoc Trung. 2019. "Corruption, Agency Costs and Dividend Policy: International Evidence." The Quarterly Review of Economics and Finance. https://doi.org/10.1016/j.qref.2019.09.010.

Trifonova Price, L. (2019). Media Corruption and Issues of Journalistic and Institutional Integrity in Post-Communist Countries: The Case of Bulgaria. 
Communist and Post-Communist Studies, $52 \quad$ (1), 71-79. https://doi.org/10.1016/j.postcomstud.2019.02.005.

Ullah, B. (2019). Financial Constraints, Corruption, and SME Growth in Transition Economies. Quarterly Review of Economics and Finance, 53(June), 25-68. https://doi.org/10.1016/j.qref.2019.05.009.

Wang, B. \& Zheng, Y. (2019). A Model of Tournament Incentives with Corruption." Journal of Comparative Economics, 47(5), 1-16. https://doi.org/10.1016/j.jce.2019.09.003.

Zhang, H. et al. (2019). Anti-Corruption Efforts, Public Perception of Corruption, and Government Credibility in the Field of Real Estate: An Empirical Analysis Based on Twelve Provinces in China." Cities, 90(March), 64-73. https://doi.org/10.1016/j.cities.2019.01.042.

Zhang, J., Quan, S. \& Jiang, J. (2019). Corruption and Private Firms' Survival in Transition Economies: Evidence from China. China Economic Review, 57(January), 101339. https://doi.org/10.1016/j.chieco.2019.101339. 


\section{QUOTE}

\section{It is not power that corrupts but fear. Fear of losing power corrupts those who wield it and fear of the scourge of power corrupts those who are subject to it.}

Aung San Suu Kyi, Freedom from Fear

Human Rights Activist and Leader of Burma's National League for Democracy 